\title{
Deconstructivism in Philosophy, Architecture, and Reusability Contribution
}

\author{
John Barsoum
}

\begin{abstract}
Interest in philosophy and the humanities increased after the Second World War, especially in the West, as the critical movement began to reconsider the Western intellectual and philosophical heritage, and emerged approaches known as" postmodernism“, as critical foundations of Western cultural thought, and a product of that cultural and cognitive movement known as" postmodernism"; the concept of postmodernism, which is central This term is associated with a very diverse group that is rarely associated with each other with common things. The idea of postmodernism appears in a critique of the literary and philosophical trends on which modernism was based, and some theorists and philosophers believe that postmodernism is closely related to the social and political transformations that took place in industrial societies such as the postindustrial or knowledge society. Deconstruction is important critical movement as well as controversial, and no theory in literary criticism has provoked waves of admiration and created a state of aversion and resentment as well, as deconstruction has done in contemporary literary thought. Deconstruction emerged in the 1960s as a reaction to structuralism, the dominance of language, the centralization of the mind, and the dominance of linguistics over all fields of knowledge, and from the 1970s deconstruction became a literary critical methodology, and a mechanism for evaluating rhetoric and interpretation. Deconstructionism is mainly a critique of the structural proposition, which has been working to reveal the basic structures responsible for the most noticeable features of social and cultural interaction, since deconstructionism consistently negates the meaning in the text system and analyzes the margins, gaps, expectations, contradictions and conclusions within the texts, as formulations that contribute to the disclosure of the background of language and structure.
\end{abstract}

Keywords: Deconstruction, Architecture, Reusability, Philosophy

\section{INTRODUCTION}

$\mathrm{D}$ errida, who was born in 1930 and matured as a young man with the beating of World War II drums, had tangible influences on architecture and even contributed directly to the design process with the famous architect Peter Eisenman in the Lafayette Park project in the support and instigation of the architect Bernard Chome. Derrida saw architecture as a kind of creative writing, thus it is a way of practicing life, and he called for what defined architectural differences or differences, where architecture can create places where desire

Manuscript received on February 05, 2021.

Revised Manuscript received on February 12, 2021.

Manuscript published on February 28, 2021.

* Correspondence Author

John Barsoum*, Department of Civil Engineering, Peoples' Friendship University of Russia (RUDN), 6 Miklukho Maklaya St., Moscow, 117198, Russian Federation; Email: 1032185626@rudn.ru

(c) The Authors. Published by Blue Eyes Intelligence Engineering and Sciences Publication (BEIESP). This is an open access article under the CC BY-NC-ND license (http://creativecommons.org/licenses/by-nc-nd/4.0/) can exist and live. Derrida criticized the fierce criticism of his contemporaries in which they relied on describing deconstruction as a kind of nihilism that undermined and weakened the vital moral and intellectual standards of the Academy. Some even claim that Derrida's theories are suicidal, meaning that they put an end to their own life. When asked what deconstruction is, Derrida replied: I cannot find a simple answer to this question. He went on to say that all of my lectures and articles were an attempt to avoid this enormous and terrifying question at the same time.

\section{FOUNDATION OF DECONSTRUCTION}

Derrida tries to reach a stable position in the heterogeneous textual structure where Derrida provides the basis for the idea of deconstruction:

- Difference: Derrida believes that the difference requires the existence of multiple interpretations and suggests the existence of multiple facts as well as the existence of one fact and one interpretation, based on the description of the meaning at length, and not to undergo a stable situation, and the difference shows the status of the text in the possibility of providing the reader.

- Nihilism of centralization: the undermining of centralization at Derrida leads to the destruction of all centers, and the dismantling of their systems starting from the center of everything, which (God) is a central reason for all events, passing through the center of truth, and ending in the center of rationality, and the intentionality of this Derrida is heading to the principle that requires counting signs in a continuous.

- Undermining metaphysics: Derrida proclaims the end of metaphysics along the lines of Martin Heidegger, Derrida criticizes logic, language, presence, and rational centralization that constitute the standard of truth, intuitiveness, and certainty.

- Critique of identity, privacy and original roots: Derrida rejects mental centralization and abhors any introversion of race, roots, bravado of privacy and centralization, or belief in the dominance of one element over another.

- Deconstructing the concept of history: Derrida rejects classical history based on one dominant voice and calls for a new multi-voice historicism, concerned with peoples living on the sidelines.

- Deconstruction of texts and discourses: Derrida adopts the deconstruction mechanism in undermining texts and dissecting discourses, whether literary or philosophical, and what matters to Derrida in the readings he tries to establish is not criticism from the outside but stability or positioning in the heterogeneous structure of the text.

Published By: Blue Eyes Intelligence Engineering and Sciences Publication

(C) Copyright: All rights reserved.

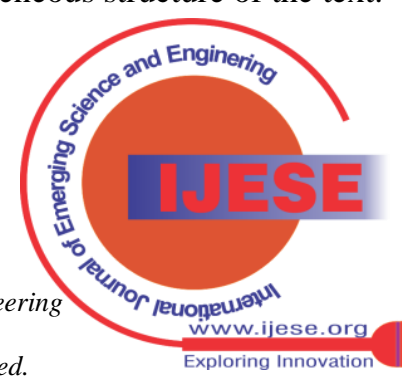


- Multilingualism, meanings, and texts: Derrida defines deconstruction as not believing in one language and believing in multiple languages through mechanisms of difference, contradiction and dialogue.

\section{DECONSTRUCTING IDEAS AND DECONSTRUCTING CONSTRUCTIONS}

Each idea is determined by the language through which it tries to communicate with other minds, the language is not a vessel or a tool for communication according to classical linguists, but the language has become an intellectual tool that determines thinking and mental upbringing, which means that man thinks according to his language. In addition to the relationship of ideas to history, each idea arises in a specific time and in a certain place, and every time there are certain postulates and rational premises prevailing affect thoughts and thinking. And disassembly tools examine the idea in terms of coherence, logical proof, scientific, nondevelopment or clash with the other information fixed, and by fixed it has been proven through scientific experiment and possess evidence of strong logical - such as no one can claim that the Earth is flat, despite scientific evidence and indicate the roundness of the Earth. Deconstructing the idea means dissecting it and re-synthesizing it to clarify the internal contradictions that exist in the idea. Thus, these different dimensions should be considered when trying to disassemble ideas; let's take an example: Aristotle believed that male teeth were more numerous than female teeth. If we try to deconstruct this idea, we start from its history. We point out that this era was not experimentation as a scientific approach, but meditation was the dominant approach. Therefore, Aristotle did not adopt experimentation as a scientific approach, and did not bother to look at his wife teeth. This observation points to the contradiction that exists within the idea. it also points out that women in this Greek era were inferior to men. we explain the fragility of this perception because it was one of the postulates on which the idea is based, because the idea is unable to depart from the prevailing approach and the certainties known in its time. This idea is therefore not coherent in terms of scientific evidence and evidence. From the historical tracing we observe the main trends in contemporary philosophy in the twentieth century, namely: the movement of modernity, then postmodernism, followed by phenomenology, structuralism, and post-structuralism, from which the deconstructive philosophy stemmed. The efforts of Jacques Derrida (1930-2004) and his contemporary Roland Barthes (1915-1980) had the greatest impact in the formulation of post-structuralism philosophy. Later he declared that the death of the author also meant the birth of the reader who had the full right to a plurality of meanings and interpretations by which he received the creative work.

(Giedion, S.(1967))

However, other critics of the literary movement believe that the defining moment in the scene of the birth of deconstructive philosophy is the famous Derrida lecture entitled "Structure, Mark and Play in the Concept of Human Science" where he proposed the idea of departing from the center in our cultural worlds instead of developing or deviating from the same declared center The well-known and emphasized the importance of play and difference as alternatives to deconstruction, and as the banker (2003) suggests, it was Jacques Derrida who announced the death of the book and the beginning of writing as an expression of the new era. The main field that the French philosopher's treatise deals with is the field of philosophy and literary criticism, but it quickly expanded in its influence to include other creative fields such as plastic arts and architecture. Derrida used the term deconstruction from earlier formulations by the philosopher Martin Heidegger in which he proposed that construction interferes with demolition, which was interpreted as deconstruction. Indeed, an examination of the historical background shows that Derrida was influenced by the external and the structural, then he produced deconstruction from the post structural umbrella. Deconstruction has affected all aspects of life and changed the concepts of many From thinkers, theorists and academics, it has also deeply affected the creative movement, especially novel, literary criticism, music and architecture, which will be emphasized. Focusing on the contributions and theses of Jacques Derrida in the formulation of deconstruction as a term and as a philosophical approach has radically influenced architectural creativity is the focus of this part. Derrida in his early works reiterated that deconstruction is the shaking or trembling of the edifice as a total being and thus what he called the trembling and trembling of immortality occurs. Deconstruction is a confusing term, and many have hesitated to define it, including Derrida himself, as we have already mentioned, especially when he was asking how to interpret it in an architectural context and concepts, and as evidently poses (1993). Deconstruction is a framework or type of intellectual interrogation that shakes the building in a way that reveals its weakness. It puts construction under pressure. In Derrida's view, deconstruction is not destruction, but the ability to reveal and deconstruct the constituent layers of the building. He here adopts Martin Heidegger's idea that deconstructive destruction or abstinence confuses, disrupts, and disturbs tradition. Deconstruction wonders about the thesis, the hypothesis, the main idea, and the positivism of almost everything without exception (Norris C. (1991)).

Derrida intentionally called deconstruction, the processes that he followed to discover new approaches to philosophical thought in particular and human thought in general, but he stressed that there is no deconstruction without the memory of traditions, and it began from the traditional philosophical history documented in its different epochs, then began questioning and criticism, creating a series of successive shocks of the classes that were formed across History by interrogating all the hypotheses that were considered in an earlier time not questionable and not subject to any doubt. Hence, what Derrida calls deconstruction is not a comprehensive theory and not an organized fabric of ideas but rather a strategy and method for reading a philosophical or literary text to reach their depths and probe their depths.

Derrida's deconstructive strategies - like that of Sigmund Freud's psychological theories and Karl Marx's political theories - later formed an important aspect of postmodernism, especially in the field of post-structuralist literary theory and text analysis. Text analysis is the process by which the reader is able to uncover the meaning and decipher the content through textual contradictions or binaries and duplications.

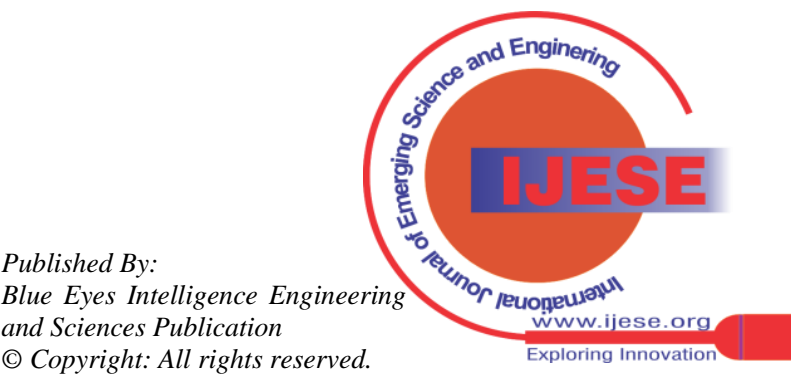


The main effect of deconstruction is that what appears to be coherent and homogeneous is in fact that it contains contradictions and conflicts that the text cannot contain and make them static and stable. From here emerges Derrida's idea of the nonfulfillment of the meaning and the permanent delay of this mechanism, or the so-called deferred and indefinable meaning. Hence, the meaning of it is an extended horizon that is not verifiable, and whatever we move towards it, it is variable, shifting, and dynamic.

\section{ARCHITECTURE AND PHILOSOPHY}

In understanding the nature of the relationship, the development and maturity of new concepts in any culture is reflected in different ways on all walks of life, but architecture stands out as one of the most important creative areas that can reflect and embody new philosophical and intellectual concepts and visions. Among the most important philosophers and thinkers whose ideas have had a sweeping and decisive influence on architecture are Martin Heidegger and Jacques Derrida, but the most important is their concern for the manner, style and design processes by which architecture will reflect their philosophical ideas. Philosophy uses architecture to embody its ideas and denies the idea that architecture is a material practice only, and architecture resorts to philosophy as it is proposed (Wigley, 1993) to formulate an entity that carries deep contents and dimensions that qualify it to transcend its material imperative. As for (Nelson, 2004) he argued that architecture is a constructive an expression of multiple ways of thinking, and he added that this complex relationship in architecture was tested in different ways in the works of influential architects such as Bernard Chome, Daniel Libeskind and Peter Eisenman. The interaction between philosophy and architecture is evident and evident not only in Derrida's writings, but also in his collaboration with architects such as Peter Eisenman and Bernard Chome in Lafayette Park, which was an area for embodying Derrida's deconstructive ideas in architecture, as we shall explain later.

\section{DECONSTRUCTION AND ARCHITECTURE}

On the sidelines of the author's death and the death of the architect, what Derrida proposed is an open and flexible critical framework which he called the "strategy of deconstruction", which he defined as not a demolition but rather a reconstruction, synthesis and dissection of all meanings and concepts, and this is what is required to be understood in any attempt to test or evaluate or even just Trying to understand the relationship between deconstruction and architecture. The term "deconstructive architecture" was crystallized at the end of the eighties of the twentieth century, as a symbolic and theoretical expression at the same time of a set of design trends and experiments that appeared in the international architectural practice and all were based on the philosophical proposition of Jacques Derrida. As Derrida emphasizes, deconstruction is not an architectural "style", but rather a "method, strategy, or vision" adopted by the architect with the aim of creating a "conflict and collision" between what has become a normal and familiar thing for a person to perceive language and meaning, and what he sees or witnesses. Architectural deconstruction, in this sense, and according to Derrida, is like asking the architects themselves: metaphor in philosophical thought and at the same time it is

Can architecture give up the domination of classical aesthetics, can it shy away from utilitarianism, from functionalism, and whether there are well-established concepts that define order, and also indicate lack of System to jam, for example; Is it possible to construct a building by abandoning those basic principles that are known and familiar to create an architecture, including principles: rhythm, balance, horizontal and vertical lines? Or is there another architecture that necessarily seeks to break down the old values in order to create something new (Asensio, $\mathrm{N}$. (2004)).

The architect who is interested in answering these questions must first get rid of old concepts and beliefs to formulate the architectural work and void, and he must also strive himself and intensify his creative effort in order to create new forms, new spaces, and even new types of buildings. In other words, deconstruction means seeing the faculty of architecture and its comprehensiveness in its fragmentation, anatomy and reconstruction, not with the vision of modernity that deals with the purity of form and the frankness of the architectural block and its visual regularity. In fact, deconstruction may show the building lacking visual logic, but the auditor finds that visual logic exists, but it is a logic rebellious against the old rules. To provide an unprecedented spatial and optical configuration. The team of architects who create according to the concept of deconstruction in architecture, creating a new architecture that does not at all resemble the starting points of the usual architecture and does not depend on its familiar references. It is a special product that enriches the global architectural discourse with new formations and spatial experiences and different concepts. Peter Eisenman, Frank Gehry, Bernard Chome, Christian D. Portzpark, Zaha Hadid, Reem Koolhaas, Daniel Libeskind and others are among the most important architects who adopted the methodology of deconstruction. They are all the generation that can be described as rejecting the vulgarity of postmodernism in architecture, especially in terms of the naive and superficial use of classicist historical styles. Among the defining moments in the history of deconstructive architecture comes the incident of organizing the exhibition "Deconstructive Architecture" in 1988 at the Museum of Modern Art in New York City, USA, which was jointly organized by the writer and architectural critic Mark Wigley and the famous architect, the creator of the new Louvre pyramid, Philip Johnson. The pure masses have ended and the classical engineering formation traditions, such as balance, gradation and harmony, have already been rebelled in favor of producing dynamic and unstable engineering structures, but according to Evangel's expressions, they may be uncomfortable and visually disturbing because they offer a new language and an architectural era different from the prevailing one. The exhibition presented the works of seven architects representing the new trend, the most important of whom was the American architect, Peter Eisenman, who was the first to propose the idea of decentralization or to reject the center, as he discovered from Derrida's proposal to analyze the literary text, and then began a creative and academic project to search for new aesthetic values (Aida Hoteit (2015)). and Sciences Publication

(C) Copyright: All rights reserved. 
Also one of the defining moments that attracted the attention of the critical and academic architectural circles is Jacques Derrida's comment on the architect Bernard Chome's victory in the international competition for planning and designing the Park La Fayette in Paris in France, which contains a group of buildings and spaces designated for the distinct practice of all artistic, entertainment, scientific and musical activities, where Derrida emphasized that "' the project succeeded in dismantling all connotations of architecture; It leads to the instability of the meaning and its uncertainty. Or what might be called the concept of "anti-architecture"? which loses the latter itself, its aesthetic aura, its entity, or its elegance? But the reality is that the project aims to produce, attribute, renew and "rewrite" architecture, and it may revive the energy that has been frozen, concealed, sealed, and buried in a collective grave called nostalgia that was consumed by postmodern architecture or some of its architects (Aida Hoteit (2015)).

One of the most prominent architects of deconstruction is Zaha Hadid, who is the only architect who possessed the daring of rebellion and declared her belief in Derrida's ideas. This phase of focus on being present in the important architectural competitions until the opportunity came to the first construction of a small building, the fire station attached to the Vitra Furniture Factory and Museum designed by Frank Gehry, and it enabled observers of the global architectural scene to present a unique plastic and spatial experience in a highly functional and functional building. As a general framework for deconstructive architecture, by employing streamlined, curved, oblique, flexible and organic forms, and emphasizing the use of the vitality of the contrast between space and mass, a system that signals a sense of "disorder", which the pioneer of deconstruction is keen on: "Derrida" always reminds us of it, the complexity of the visual experience and the multiplicity of the interpretation of the architectural product that characterizes this architectural school And follow it. Thus, we can limit the fundamentals or principles of deconstructive architecture, but they combine in that they present to the creator infinite scenarios, various interpretations, and endings that are difficult to predict, the most important of which are: research and fragmentation in the unconscious instead of researching history, spatial and plastic dynamics, and keenness to create moving buildings characterized by changing the visual image instead of Its stillness, its rigidity, and the preference for the dynamic equilibrium of the building over the classical monogastric equilibrium, as well as the eccentricity and eccentricity of formation, confirm Derrida's idea of rejecting the center.( Norris C. (1991)) From the plastic point of view, we notice essential features such as placing the columns at angles that attract complex and visual complexity, and are crooked and inclined, and the interfaces carry a complex visual and plastic language, loaded with questions and exciting for dozens of interpretations and interpretations by the recipient, and the emphasis on the dynamic engineering structure by designing on geometric networks in all three-dimensional directions confirmed by The intersecting corridors and the intertwining walls are irregular in rhythm. As the famous architectural thinker and critic Charles Jenkins, who is one of the most important analysts of modernity thought in architecture, argues that deconstruction is the architecture of fracture, asymmetry and asymmetry, an architecture full of unexpected surprises and uses the vocabulary of classical architecture in a mirrored or distorted way, which is Classical and anticlassical architecture. He also stresses that deconstruction and post-modernity, despite the obvious and radical differences between them, but they agreed on a fundamental thing, which is difference, dimension and criticism of everything that is traditional and familiar. The creative product of the international architect Peter Eisenman is always faithful to deconstruction and is closely related to it, and he is the largest representative of this distinctive design trend in the global architectural scene. Eisenman's product was considered a direct architectural embodiment of the philosophical deconstruction doctrine, and he never felt embarrassed by this description, rather, he was declaring his devotion to deconstruction in a clear and unambiguous way in the many interviews that were conducted with him, and in the many articles he wrote. Even the books he wrote were full of his belonging and pride in deconstruction. He also had the opportunity to conduct a series of important conversations with Derrida himself to develop a vision of architecture based on the essence of deconstructive thought (Wigley, M. (1993), Saussure, F. (2002)). Eisenman has sided with deconstructive theses. His distinctive works, which reflected the deconstructive approach, began to appear in succession. The architectural circles continued well his numerous design studies on investigating a new architecture for a "residential house" (let us remember the second house 1969-1970, the sixth house 1972-1975, and the tenth house 1975) - through which he continued to enrich the postmodern architectural discourse with new forms based on the starting points. Uncommon in a radical "reinterpretation" of the residential home concept and its design form as it promotes deconstruction. There are many projects designed by Peter Eisenmann in the 1980s and 1990s, for example the Wexner Center for Visual Arts (1983-1989) in Ohio / America, the Bioscentrum project (1987) in Frankfurt / Germany, and the Guardiola circuit project (1988). ) In Cadiz / Spain, and the headquarters building of "Nonutani (1990-1992) in Tokyo / Japan, and the" Max Rinhar "building project (1992) in Berlin / Germany, as well as the project of" Du Kai Branly "museum (1999) in Paris / France And other implemented and unimplemented projects are all united by Eisenman's special architectural reading of deconstruction; they are milestones in the accomplishment of this approach as they are projects that, according to the visions of many critics who follow postmodern architecture, are highly important events in the building record. For that architecture in general. More importantly, "Peter Eisenman" did not limit his belief in "deconstructive" thought to the design practice through which he produced buildings that many interested critics considered as events of particular importance in the architectural scene (Proimos, C. V. (2009). Rather, it goes beyond the academic side, where Eisenman, the "teacher" and a prominent university professor, actively promoted deconstruction through his lectures and permanent encounters in the educational community, and through his numerous written publications and writings, which promoted that design approach that now enjoys the admiration and sympathy of many architects eager to enrich the discourse. World Architect and its diversity of sources.
Published By: Blue Eyes Intelligence Engineering and Sciences Publication (C) Copyright: All rights reserved.

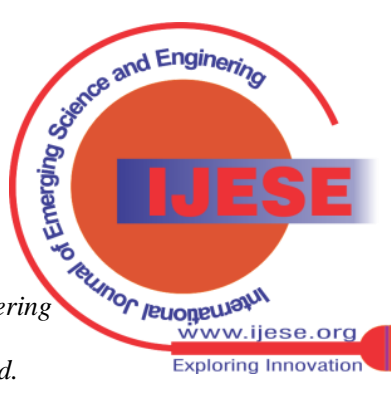




\section{CONCLUSION}

In conclusion, we review the most important criticisms, as the deconstruction itself was subjected to another deconstruction, especially from the United States of America, and they noted that deconstruction first: an ambiguous philosophical vision in its theoretical and methodological presentation, and that its concepts and concepts are more complex, difficult and vague. Second: deconstructionism as a radical ideology imbued with Karl Marx's revolutionary ideas, it counts on the politics of the left; third: deconstructionism attempts to decentralize the mind using other rational foundations; and fourth: it is an anarchist nihilistic philosophy that tries to destroy historical intellectual foundations but is unable to break them. The future of deconstruction and the birth of the architect of the 21st century The deconstruction that called for the death of the author and the birth of the reader in literary creativity made a radical contribution to architecture and architects, and I particularly think that deconstruction has announced the birth of a new architect for the new century or the new millennium. This architect got rid of the mono-architectures of the previous architecture, such as focusing on function only, construction, or even the classic aesthetic and void experience known to the end that does not carry the drama of surprise, as it is not concerned with reading the recipient and how he merges and experiences the space or the architectural space. What Jacques Derrida did for architects can be described as an unprecedented process of liberation that has produced and will produce for the human community in all parts of the earth a new architecture that we may disagree with, but we can only agree on its boldness, presence, and excitement of thought and question and this is the essence of creativity.

\section{REFERENCES}

1. Asensio, N. (2004). Great Architects, Atrium Group, Barcelona, Spain

2. Banham, R. (1975). Age of Masters, The Architectural Press, London.

3. Ching, F. D. K.(1974). Architecture: Form, Space \& Order, Van Nostrand Company, Inc., New York

4. Aida Hoteit (2015) Deconstructivism: Translation From Philosophy to Architecture. Canadian Social Science, 11(7). P. 117-129.

5. Giedion, S.(1967). Space, Time and Architecture, Cambridge, Massachusetts, Harvard University Press.

6. Kaufmann, E. \& Ben Raeburn. (1960). Frank Lloyd Wright, Writings \&Buildings, Horizon Press, INC, U.S.A.

7. Norberg-Schulz C.(1974). Meaning in Western Architecture, Studio Vista, London.

8. Norris C. (1987) Derrida. Fontana, London.

9. Norris C. (1991) Deconstruction Theory and Practice. Routledge, London

10. Papadakis,A., Cooke, C., \& Benjami n, A. (1989). Deconstruction. New York: Rizzoli. Powell, J. (1997). Derrida for beginners. New York: Writers and Readers Publishing.

11. Proimos, C. V. (2009). Architecture: A self referential sign or a way of thought? Peter

12. Eisenman's encounter with Jacques Derrida. South African Journal of Art History, 24(1), 104-120.

13. Saussure, F. (2002). Ecrits de linguistique generale. Paris: Editions Gallimard.

14. Van der Straeten, B., \& Masschelein, A. (2003). The uncanny and the architecture of deconstruction. Image \& Narrative, 5.

15. Wigley, M. (1993). The architecture of deconstruction, Derridas Haunt. USA: MIT press.

16. Neil Leach, Rethinking Architecture a Reader in Cultural Theory, Routledge, London, 1997.

17. Jonathan A Hale, Building Ideas an Introduction to Architectura Theory, John Wiley \& Sons Ltd, Chichester,England,2000.

18. Mark Wigley, The Architecture of Deconstruction, Derrida's Haunt, MIT press, USA, 1993.

19. Fredrik Nilsson, 'philosophy and the development of architectural thinking'-congress

CATH04 http://www.leeds.ac.uk/cath/congress/2004/programme/abs/114.shtml

20. Peter Noever, Architecture in Transition, Between Deconstruction and New Modernism, Prestel, Munich, 1991.

21. Jonathan Glancey, 20th C Architecture, The Structures that Shaped the Century, Carlton Books ltd., London, 1998.

22. Kate Nesbitt, Theorizing a New Agenda for Architecture, An Antology of Architectural Theory 1965-1995, Princeton Architectural Press, New York, 1996.

23. Jeffrey Kipnis and Thomas Leeser, Choral L Works, Jacques Derrida and Peter Eisenman, The Monacelli Press, Inc., New York, 1997.

24. Bernard Tschumi, Architecture and Disjunction, the MIT Press, London, 1996.

25. Jonathan Culler, On Deconstruction, Theory and Criticism after Structuralism, Cornell University Press, USA, 1983.

26. Jonathan Loesberg, Aestheticism and Deconstruction, Pater, Derrida, and de Man, Princeton University Press, USA, 1991.

27. Peter Eisenman, Peter Eisenman, Diagram, Diaries, Thames and Hudson Ltd., UK, 1999.

28. Aaron Betsky, Zaha Hadid, The Complete Building and Projects, Rizzoli International Publications, Inc., New York, 1998.

29. http://jamesfaulconer.byu.edu/deconstr.htm

30. http://www.hydra.umn.edu/derrida/sign-play.html

31. http://lucy.ukc.ac.uk/simulate/derrida deconstruction.html

32. http://www.public.asu.edu/ jchakrab/deconstruction.pdf

33. http://www.gardenvisit.com/landscape/architecture/18.2-metaphysicsparc-villette.htm

34. http://www.andrew.cmu.edu/user/atk/peter\%20eisenman.pdf

35. http://www.designboom.com/eng/interview/eisenman.htm

\section{AUTHORS PROFILE}

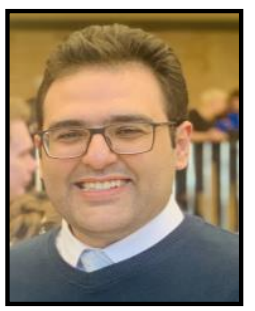

John Barsoum is currently a master's student in Civil engineering and built environment at Department of Civil Engineering, Peoples' Friendship University of Russia (RUDN), 6 Miklukho Maklaya St., Moscow,117198, Russian Federation; He received BE (Hons) degree in Civi Engineering and infrastructures from Higher technological institute $10^{\text {th }}$ of Ramadan city, Arab Republic of Egypt (HTI) in August 2016. He also. He also worked with Orascom Red sea constructions (RSC), Egypt as Technical office engineer responsible for issuing technical shop drawings, claims and Quantity surveying sheets in the period of 2016-2019. He is the "2019 Egyptian winner of Education-in-russia.com Scholarship" for master's degree in civil engineering, He is a Registered Engineer (Civil Engineering Department) in the Egyptian Engineers Syndicate (EES) of Egypt.

Published By: Blue Eyes Intelligence Engineering and Sciences Publication

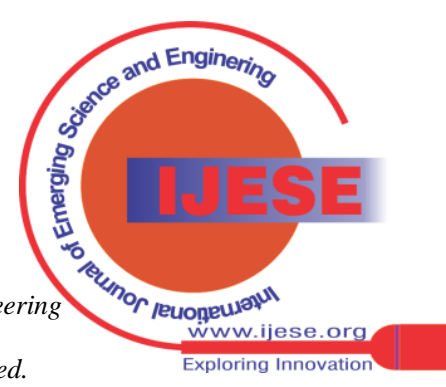

